\title{
Bovine Immunoglobulin E Levels of Bali Cattlesin Bangli and Nusa Penida island Bali Province, Indonesia
}

\author{
Ni Ketut Suwiti ${ }^{1}$, Luh Gde Sri Surya Heryani ${ }^{2}$, Desak Nyoman Dewi Indira Laksmi ${ }^{2}$, \\ Ni Nyoman Werdi Susari² ${ }^{2}$ I Nengah Kerta Besung ${ }^{2}$. \\ ${ }^{1}$ Centre for bali Cattle Studies Udayana University \\ ${ }^{2}$ Fakulty of Veterinary Medicine, Udayana University \\ *Corresponding Author: nk_suwiti@unud.ac.id
}

\begin{abstract}
The aim of this research was to detect identify levels of Bovine Immunoglobulin $\mathrm{E}$ (BoIg.E), can be used as an indicator of response immune in bali cattle. Eighty serum samples were collected from Nusa Penida and Bangli region. Bovine Ig.E levels was measured using a commercial Enzyme Linked Immunosorbent Assay (ELISA) Kit. The data were analysis based on differences of farming characteristics andgeographic. The result of research that, of BoIg.E level of bali cattle kept in Bangli $(34.16258 \mathrm{\eta g} / \mathrm{ml})$, was higher than Nusa Penida (22.26047 $\mathrm{ng} / \mathrm{ml})$. We conclude that there was a significant effect of differences of farming characteristics and geographic conditions.
\end{abstract}

Key words: Bali cattle, Bovine Immunoglobulin E, Nusa Penida island, Bangli regency

\section{INTRODUCTION}

Bali cattle is an indigenous cattle breeds in Indonesia [1]. One of the important beef cattle breeds and the most predominant genotype within the eastern islands, e.g. in Bali, East Nusa Tenggara and West Nusa Tenggara provinces [2]. Bali cattle is a direct descendant of wild banteng (Bos javanicus), in Indonesia still available in Baluran National Park, East Java [3]. Therefore, it is important to increase reproduction and productivity and be kept purity. This breed is predominant in Indonesia, due to its resilience in tropic condition [4].
In Bali Province, bali cattle was reared in three different types of preservation areas in Bali Province namely gardens, fields and cultivated lands. In Nusa Penida Island was founded by the government as a breeding center of pure bali cattle. Bali cattle was raised in Nusa Penida in fields and cultivated lands with semi-extensive, meaning that the animal was partially stored in a stall with irregular weeds [5][6]. The other region of Bali Province for example in Bangli regency, bali cattle rare in with intensively management keep install and given additional feed, like mineral mixed. 
Besides the differences on type of raising, geographic conditions between two regions are also different. Nusa Penida is an island with sloping and hilly land, tropical climate with low intensity of rainfall (1562.67 $\mathrm{mm} / \mathrm{year})$ air temperature ranged on $30,9^{\circ} \mathrm{C}$ (RPJMD, 2008). While Bangli is one of the high lands in Bali, with relative air temperature ranged between 150 - 300C, high intensity of rainfall, specifically: $3.500 \mathrm{~mm} /$ year. The differences on geographic and ways of management, caused a difference on immune response [7]. Proven by the fact that the bali cattle in Nusa Penida was free of Jembrana disease and Septicemia epizootica diseases.

A good immune response marked by how the animal's resistance to disease. As an indicator is the appearance of antibodies in the body that can be measured in the form of immunoglobulin existence. There are five classes of immunoglobulins: IgG, IgA, IgM, IgD and $\operatorname{IgE}$ [8]. The Immunoglobulin $\mathrm{E}$ (BoIgE) is most commonly associated with allergicdisease and believed to mediate an exaggerated and/or mal-adaptive immune response to antigens[9]. $\operatorname{IgE}$ is extremely biologically active despite the low concentrations in the circulation [10].
Here we describe the level of bovine $\operatorname{IgE}$ in bali cattle in various method of raising in Bangli and Nusa Penida islands. The two separated islands represent different geographic, land fertility and cattle raising practices.

\section{RESEARCH METHODS}

Eighty serum samples of bali cattle from each area were selected using random sampling in two area. In Nusa Penida, namely, Batumadeg and Ped, and Bangli, namely Sale and Bebalang villages. The whole blood was drawn from jugular vein and collected using venoject10 $\mathrm{ml}$ vacuum tube without an anticoagulant agent, and followed by serum isolation

\section{Immunoglobulin E measurement}

The BoIg.E was measured using Bovine Immunoglobulin Enzime Linked Immunosorbent AssayKit [11], and conducted in accordance to the protocol described. Briefly, Bring all reagents to room temperature. Dilute the standard: pipette $50 \mu \mathrm{l}$ standard dilution in each tube. Pipette $100 \mu \mathrm{l}$ standard $(900 \mathrm{mg} / \mathrm{ml})$ in the first tube and take out $100 \mu 1$ from the first tube into the second. Pipette $50 \mu \mathrm{l}$ from the second tube to the third tube. 65 
Repeat each of the concentration to get the mean value of each well. Pipette standard $50 \mu$ l to testing standard well. Set blank wells separately (blank comparison wells don't add sample and HRP-Conjugate reagent, other each step operation is same). Pipette sample dilution $40 \mu$ to testing sample well, then add testing sample $10 \mu$ (sample final dilution is 5-fold), pipette sample to wells, don't touch the well wall as far as possible, and mix gently. Incubate: cover with the adhesive strip provided, incubate for $30 \mathrm{~min}$ at $370 \mathrm{C}$, Configurate liquid: dilute wash solution 30-fold with distilled water. Washing: uncover the adhesive strip, discard liquid, pipette washing buffer to every well, still for 30 s then drain, repeat 5 times.Add enzyme: pipette HRP-Conjugate reagent $50 \mu 1$ to each well, except blank well.Incubate: operation with, Washing: operation with 5, Color : Pipette Chromogen Solution A 50uI and Chromogen Solution B to each well, avoid the light preservation for 15 $\min$ at $370 \mathrm{C}$. Stop the reaction if the blue change to yellow. Read absorbance at $450 \mathrm{~nm}$ after pipetting Stop Solution within $15 \mathrm{~min}$.

\section{RESULTS AND ANALYSIS}

The profile of individual cattle based on type of raising and geographic conditions are presented in figure 1. The figure indicate that the individual Bovine Ig.E level was mixed population which tends to be higher in Bangli regions bali cattle. We found that the BoIg.E level of bali cattle kept in Bangli area: 34.16258 $\eta \mathrm{g} / \mathrm{ml}$ and Nusa Penida area: 22.26047 $\eta \mathrm{g} / \mathrm{ml}$. 


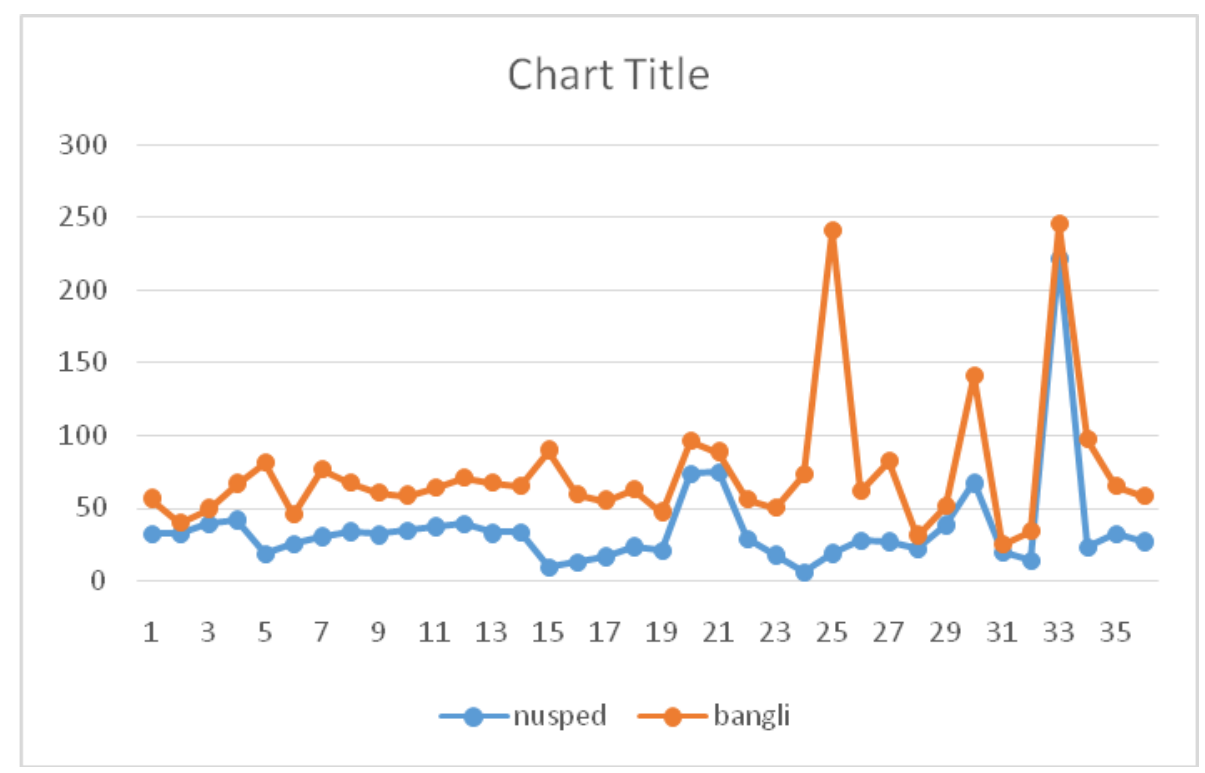

Figure 1. BoIg.E. levels of Bali Cattle in Bangli and Nusa Penida island

The BoIg.E level of bali cattle kept in Bangli area was higher than Nusa Penida. This is caused by the differences to the management of bali cattle, nutrients, and geographical conditions. Bali cattle in Nusa Penida with free grassing animal raising practices, and in Bangli keeping animal in the stall and given a mineral mixed.

The differences ways of treating caused difference at the intake of nutrients absorbed by the bali cattle. Bangli regency is a region with plantation and fertile soil. It soils fertility related with the presence of minerals in the soil, its subsequently absorbed and utilized by the plants and used as Bali cattle's food source in Bangli. Some minerals such as $\mathrm{Cu}, \mathrm{Fe}$, and $\mathrm{Zn}$, are indispensable to improve body resistance [12]. One of the body resistance indicators is, the presence of antibody, that characterized by increased of IgE level.

Bali cattle rising with intensive (stall) management and given additional feed. Feed additive formed as a mineral mix that able to increase the growth and immune responses. Feed supplement given in the form of additional minerals on the feed. In pig feed supplement can influence the bioavailability of several micronutrients important for the immune response ( $\mathrm{Fe}, \mathrm{Cu}, \mathrm{Mn}$, and $\mathrm{Zn})$ and to assess if the dietary supplementation could potentiate an immune response which would improve pig health status after weaning [13]. Trace elements are 67 
implicated in many physio-logical processes contributing to the body's natural defenses on three levels: support for physical barriers (skin/mucosa), cellular immunity, and antibody production [14]. Supplementation with these micronutrients support also a Th-1 cytokine mediated immune response with suffi-cient production of pro-inflammatory cytokine, and enhanced innate immunity[15] [16].

The lower level of IgE at bali cattle on Nusa Penida caused by the lack amount of feed source that caused by the low intensity of rainfall and dry land. The Lack of nutrients in Nusa Penida bali cattle's food sources impact the body resistance that, marked by the reduction of antibody level, especially Ig.E. Beside it, the maintenance wasn't done intensively, so there was no additional feed that given to the bali cattle at Nusa Penida.

These differences may be related to breed, nutritional and sanitary management of the herd, and the technique used in the Ig assay [17]. Thishigh incidence of $\operatorname{IgE}$ could be due to higherincidence of parasitic infection as well as environmentalpollutants that may be allergicincreased serum IgE levels, may be due to increases in IgE-dependent processes and cellular components of the immune system [18]. The secretion of $\operatorname{IgE}$ by lymphocytes defines the allergic state of an individual[19]. This largely results from poor nutrition of cattle managed under traditional smallholder feeding systems which rely on communal grazing of overstocked and weedy native pastures [20].

The bali cattle in Bangli are managed under different and better conditions compared to Nusa Penida areas. Its therefore have a higher BoIgE. Ig.E levels influenced of allergens [21]. In Bangli regency with high land with relative air temperatures, facilitate growing parasites that can increase BoIgE levels.

In addition to being a major source of dietary calcium, milk may also raise the immune responses especially level of antibodies. The low level of serum BoIgE seems merely to be caused by environmental factor. Bangli and Nusa Penida islands are different in plantation, rainfall and soil physic-chemical properties [20]. It was plausible to draw a hypothesis that the BoIg.E level in those areas is statistically different.

There is significance different of BoIg.E in bali cattle's grown in Bangli and Nusa Penida islands. This indicates that 
the performance of the breed is influence of pasture quality. One genetic factor that leads to the low BoIgE levels of bali cattle is caused by bali cattle in Nusa Penida is pure breeds of bali cattle,due to prohibition of other region cattle to enter the region of Nusa Penida. Bali cattle are raising in Nusa Penida were originated from Nusa penida area. In addition to allergic diseases, elevated IgE levels are found in several types of immunodeficiency diseases. Production of Ig.E is modulated by many factors, including stress, exercise and nutrition.Immunodeficiency disease is very possible to happen to Bali cattle in Nusa Penida, due to lack of food sources caused by a climatic conditions with a very long summer.

\section{REFERENCES}

[1] Putra IPC, Suwiti NK, Ardana IBK. Suplementasi Mineral Pada Pakan Sapi Bali Terhadap Diferensial Leukosit Di Empat Tipe Lahan. Buletin Veteriner Udayana. 2014;8(1):8-16.

[2] Sutarno and Setyawan AD. 2015. Genetic Diversity Of Local And Exotic Cattle and heir cross breeding impact On The Quality Of Indonesian cattle. Biodiversitas.;16(2):327-354.

\section{CONCLUSION}

The BoIg.E level of bali cattle kept in Bangli: $34.16258 \mathrm{ng} / \mathrm{ml}$, was higher than Nusa Penida: 22.26047 ng/ml. The different Ig.E level was related to farming characteristics and geographicconditions.

\section{ACKNOWLEDGEMENTS}

This research was funded by Directorate General of Higher Education through Penelitian Unggulan Perguruan Tinggi (PUPT) No. 415.33/UN14.4.A/PL/2017, and the research team of Watiniasih, Suartha, Kerta Besung, for the kind co-operation and providing us the research funds to conduct this project successfully.

[3] Mohamad K., Olsson M., van Tol H.T., Mikko S., Vlamings B.H., Andersson G., Rodriguez-Martinez H., Purwantara B., Paling R.W., Colenbrander B. and Lenstra J.A. (2009) On the origin of Indonesian cattle. PLoS One, 4(5), e5490 :1-6

[4] Talib C. Sapi Bali di Daerah Sumber Bibit dan Peluang Pengembangannya. Wartazoa. 2002;12(3):100-107.

[5] Milfa S, Suwiti NK, Tenaya IWM. Profil Hormon Pertumbuhan Sapi Bali Betina Pada Tiga Tipe Lahan 
Pemeliharaan Di Provinsi Bali. Buletin Veteriner Udayana. 2015;7(1):1-8.

[6] Misrianti R, Sumantri C, Anggraini A. Polymorphism of growth hormone receptor (GHR) gene in Holstein Friesian dairy cattle. JITV. 2011;16(4):253-259.

[7] Lindell CI. Phenotyping of Bali cattle and interviewing farmers in Indonesia - a minor field study. $S L U$, Dept. of Animal Breeding and Genetics. 2013;424:1-20.

[8] Rodrigues N, Oliveira P, Borghesi J, Carolina L, Marcio M, Maria F, Miglino A. A Review, Immunoglobulin Transport during Gestation in Domestic Animals and Humans. Open Journal of Animal Sciences. 2014;4:323-336.

[9] Mann S, Leal Yepes FA, Overton TR, Lock AL, Lamb SV, Wakshlag JJ, Nydam DV. Effect of dry period dietary energy level in dairy cattle on volume, concentrations of immunoglobulin G, insulin, and fatty acid composition of colostrum. $J$ Dairy Sci. 2016;99(2):1515-1526.

[10] Vestergaard M, Purup S, Henckel P, Tonner E, Flint DJ, Jensen LR, Sejrsen K. Effects of growth hormone and ovariectomy on performance, serum hormones, insulin-like growth factor-binding proteins, and muscle fiber properties of prepubertal Friesian heifers. $J$ Anim Sci. 1995;73(12):3574-3584.

[11] Mastika IM. Feeding Strategies to Improve the Production Performance and Meat Quality of Bali Cattle (Bos sondaicus). Strategies to Improve Bali Cattle in Eastern Indonesia. Bali: Udayana University Press; 2003.

[12] Marin DE1, A. Untea1,2, P. Janczyk3,4, M. Motiu1, R.D. Criste1, W.B. Souffrant3,4Czech
Effect of dietary natural supplements on immune response and mineral bioavailability in piglets after weaningTaranu1 J. Anim. Sci., 57, 2012 (7): 332-343

[13] Wilson BK, Vazquez-Anon M, Step DL, Moyer KD, Haviland CL, Maxwell CL, O'Neill CF, Gifford CA, Krehbiel CR, Richards CJ. Effect of copper, manganese, and zinc supplementation on the performance, clinical signs, and mineral status of calves following exposure to bovine viral diarrhea virus type $1 \mathrm{~b}$ and subsequent infection. $J$ Anim Sci. 2016;94(3):1123-1140.

[14] Maggini S, Wintergerst ES, Beveridge S, Hornig DH. Selected vitamins and trace elements support immune function by strengthening epithelial barriers and cellular and humoral immune responses. $\mathrm{Br} J$ Nutr. 2007;98 Suppl 1:S29-35.

[15] Wintergerst ES, Maggini S, Hornig DH. Contribution of selected vitamins and trace elements to immune function. Ann Nutr Metab. 2007;51(4):301-323.

[16] Yuan WA, Yu XJ, Liu FQ, Wang HP, Wang D, Lai XP. Effects of trace element supplementation on the inflammatory response in a rabbit model of major trauma. $J$ Trace Elem Med Biol. 2010;24(1):36-41.

[17] Kehoe S, Jayarao BM, Heinrichs AJ. 2007. A survey of bovine colostrums composition and colostrum management practices on Pennsylvania dairy farms. J. Dairy Sci. .90:4108-4116.

[18] Eder C, Curik I, Brem G, Crameri R, Bodo I, Habe F, Lazary S, Sölkner J, Marti E. 2001. Influence of environmental and genetic factors on allergen-specific immunoglobulin-E levels in sera from Lipizzan horses. 
[19] Beveridge S and Hornig DH. 2007. Selected vitamins and trace elements support immune function by strengthening epithelial barriers and cellular and humoral immune responses. British Journal of Nutrition, 98, S29-35

[20] Dahllanuddin A, Yuliana BT, Panjaitan T, Halliday MJ, Fliert EVD, Shelton HM. 2014. Survey of Bali bull fattening practices in central Lombok, eastern Indonesia, based on feeding of Sesbania grandiflora. Animal Production Science.;54(9):1273-1277.

[21] Brien FD, Cloete SWP, Fogarty NM, Greeff JC, Hebart ML, Hiendleder S, Hocking Edwards JE, Kelly JM, Kind KL, Kleemann DO, Plush KL, Miller DR. 2014. A review of the genetic and epigenetic factors affecting lamb survival. Animal Production Science. 54:667-693. 